\title{
Integral humanisms: Jacques Maritain, Vladimir Soloviev, and the history of human rights
}

\author{
Randall A. Poole \\ College of St. Scholastica, \\ 1200 Kenwood Ave, Duluth, Minnesota, 55811, USA
}

For citation: Poole Randall A. Integral humanisms: Jacques Maritain, Vladimir Soloviev, and the history of human rights. Vestnik of Saint Petersburg University. Philosophy and Conflict Studies, 2019, vol. 35, issue 1, pp. 92-106. https://doi.org/10.21638/spbu17.2019.108

Today both the history and philosophical grounding of human rights are matters of great controversy. One prominent figure in the debate is Samuel Moyn, professor of law and history at Harvard University. He argues that universal human rights are a relatively recent concept, dating from the 1940s and that they are, more specifically, a product of the Catholic philosophy of that era. The Catholic thinker who reinvented human rights was Jacques Maritain. He was among the founders of the French philosophical movement known as personalism, which he fashioned into his own Christian (or "integral") humanism. By 1940, he was turning integral humanism into an explicit and robust defense of human rights. The Universal Declaration of Human Rights followed in 1948, and Maritain was one of its intellectual architects. Decades before Maritain, however, another tradition of Christian personalism had already developed into a theory of human rights. This tradition was Russian neo-idealism. In the late nineteenth and early twentieth centuries, it combined Orthodox Christian personalism with a Kantian conception of human dignity to produce a theoretically sophisticated defense of human rights. The leading figure in this development was Russia's greatest religious philosopher, Vladimir Soloviev. After the Russian Revolution, the intellectual legacy of Soloviev and Russian neoidealism was transmitted by Nikolai Berdiaev and the Russian philosophical emigration to interwar France, where it helped form the milieu in which Maritain's thought took shape. Indeed, Maritain's “integral humanism” is strikingly similar to Soloviev’s Christian humanism.

Keywords: human dignity, human rights, liberalism, personalism, Christian humanism, Russian neo-idealism, deification, bogochelovechestvo, Kant, Jacques Maritain, Vladimir Soloviev, Nikolai Berdiaev.

Today both the history and philosophical grounding of human rights are matters of lively scholarly debate. One prominent historian of human rights is Harvard University's Samuel Moyn, author of The Last Utopia: Human Rights in History and Christian Human Rights [1;2]. Moyn's controversial thesis is that human rights in their specific contemporary meaning are a recent innovation, dating from the 1940s. Further, he argues that at the time the conceptual basis or grounding for human rights was Christian personalism. But he suggests that personalism "should deeply unsettle prevailing opinion about what the concept of human rights implied in its founding era." He says that personalism is a highly ambiguous term; in general, it takes a "spiritual and often explicitly religious approach to the human person" [3, p. 86]. He notes that in the 1930 s it could carry reactionary connotations. By the 1940s the outstanding personalist philosopher was the great

(c) Санкт-Петербургский государственный университет, 2019 
Catholic thinker Jacques Maritain (1882-1973). His 1936 treatise, Integral Humanism, is a profound exposition of his philosophy of Christian personalism, but Maritain had not yet turned that philosophy into an explicit defense of human rights [4]. That step was taken not later than 1940 with his article, "The Conquest of Freedom," with its glowing passages on the true city of human rights [5]. In 1942 came The Rights of Man and Natural Law [6], which set the French philosopher on the path to become, in Moyn's estimation, "the premier postwar philosopher of human rights," indeed "the most prominent thinker of any kind across the world to champion rights in the postwar moment" [3, pp. 87, 90]. His 1942 book on human rights was followed by others, including Christianity and Democracy a year later and Man and the State in 1951 [6;7].

Maritain himself played an important role in preparing the Universal Declaration of Human Rights. Michael Rosen has recently called Maritain's influence "crucial"1. Soon after its founding, the UN Commission on Human Rights, chaired by Eleanor Roosevelt, commissioned UNESCO to undertake research in support of its work on an international bill of rights. UNESCO invited 150 leading intellectuals from around the world to submit papers on philosophical issues raised by human rights, especially the problem of how to ground them. Once the papers were received, UNESCO convened a special Committee on the Philosophical Principles of the Rights of Man. It met in 1947 and was chaired by Maritain, who was then the French ambassador to the Vatican and who had helped from the beginning to coordinate the UNESCO project. The research was published in a symposium, which is available on UNESCO's website ${ }^{2}$. Maritain wrote the introduction and contributed a chapter, "On the Philosophy of Human Rights". In the introduction, he says that "faith in freedom and democracy is founded on the faith in the inherent dignity of men and women." He notes that while the history of declarations of human rights is relatively recent, beginning with the English Bill of Rights (1689), the history of the idea of "the dignity and brotherhood of man" is very long [12, p. 3]. By this Maritain indicates that human dignity and human rights are distinct ideas with different intellectual histories. Today human dignity is generally taken to be the source or ground of human rights. But what, then, is the source of human dignity? That is one of the great perennial questions. It occupied Maritain — and, before him, Russian idealist and religious philosophers like Vladimir Soloviev.

Jacques Maritain was born in Paris in 1882 into a prominent family and was baptized Lutheran. At the Sorbonne he studied philosophy and science. There, in 1901, he met Raissa Oumançoff, born in Russia into an observant Jewish family that emigrated to Paris when she was eight. In the French intellectual climate of materialism and positivism, the two university students despaired over the meaningless of life and even vowed to commit suicide but were saved from that course of action by the lectures of Henri Bergson. They married in 1904. Two years later they converted to Roman Catholicism, as did Raissa's younger sister, Vera, who became a permanent member of the Maritain household. Soon, through Raissa, Jacques discovered St. Thomas Aquinas. In the decades that followed, he would become one of the century's great Thomistic philosophers. As Caryl Emerson writes:

1 "Catholic influence on the Universal Declaration of Human Rights (particularly through the Catholic thinker Jacques Maritain)... was crucial” [8, p. 53].

${ }^{2}$ It was also published [9]. On Maritain and the UNESCO project, see [10, pp. 210-211; 11, pp. 140, $160,165]$. 
Maritain's rise in the public and pontifical eye was extraordinary. At the age of thirty-two, eight years into his conversion, he received a Catholic professorship after Pope Pius X encountered his Thomist critique of Bergsonism. Four years later, in 1917, he was awarded an honorary doctorate from the Pontifical Gregorian University in Rome. Maritain's teaching career began in Paris in 1912 at the Collège Stanislas, followed by the Institut Catholique [where in 1928 he was appointed to the Chair of Logic and Cosmology]. But his influence transcended all academic boundaries when his home in Meudon (on the southwestern outskirts of Paris) became a gathering place for religious thinkers and modernists artists. From 1923 until the fall of France in 1940, the Maritains sponsored a weekly Sunday salon and an annual Thomistic study circle [13, pp. 211-212].

Beginning in the early 1930s, Maritain regularly held visiting professorships in North America. In January 1940 the Maritains left France for the Pontifical Institute of Medieval Studies in Toronto. With the war in Europe, Maritain and his ethnically-Jewish wife and sister-in-law decided not to return. They moved to the United States, where Jacques taught at Princeton and Columbia. In late 1944, he accepted appointment as French ambassador to the Vatican. He served until 1948 and then held a full-time professorship at Princeton until his retirement in 1952. He also lectured at the University of Notre Dame and the University of Chicago. After Vera's death in late 1959, Jacques and Raissa returned to France. Raissa died within several months, and Jacques moved to Toulouse to live with the Little Brothers of Jesus. He became a member of this Dominican Order in 1970. At the time of this death three years later, he was perhaps the best known Catholic philosopher in the world. His intellectual legacy includes sixty books on metaphysics, epistemology, ethics, social and political philosophy, religious philosophy and theology, the philosophy of history and the history of philosophy, aesthetics, and philosophy of education - virtually all informed by his Thomism.

Maritain's Christian tradition was French, Catholic and Thomistic. But he knew about and was close to the Russian Christian tradition, first of all through his Russianborn wife Raissa but also through the Russian religious-philosophical emigration in Paris, in which he was immersed. In arguing that Christian personalism was the conceptual grounding for human rights in the 1940s, Moyn refers to the "émigré Russian Orthodox philosopher Nicholas Berdyaev, who brought to the West an old Russian tradition of religious personalism" [3, p. 87]. Though Moyn does not develop the connection, Berdiaev and Maritain became friends after the Russian religious philosopher moved from Berlin to Paris in 1925. He was a regular guest in Meudon. The Maritains also frequented Berdiaev's home in nearby Clamart. Berdiaev's wife Lydia was a Russian Catholic, like Raissa and another Russian émigré in their circle, Helen Iswolsky, who was the daughter of the former tsarist foreign minister and ambassador to France. They were all friends; Jacques and Helen seemed especially close. In 1942, a year after fleeing France, Helen published an important memoir, Light Before Dusk: A Russian Catholic in France, 1923-1941 [14]. The "light" was Christian humanism, before the "dusk" of the Nazi invasion. Maritain wrote the foreword to the book and celebrated Iswolsky for her Christian humanism, love of freedom, and sense of human rights. Her memoir presents Christian humanism as a joint project of Maritain and the Russian religious philosophers. She names Vladimir Soloviev "the precursor of the Christian humanism of our times" and calls him her "great master" [14, p. $91 ; 15$, p. 282].

It is clear that Moyn, in referring to Berdiaev and "the old Russian tradition of religious personalism," wishes to cast doubt on Christian personalism as a viable philo- 
sophical grounding for human rights. He is more sympathetic to Kantian idealism, which grounds human dignity and personhood in moral autonomy, contrasting the Kantian conception to "the "primacy of a very different human person [the Christian personalist one] in the years when the Universal Declaration was framed" [3, p. 105]. In fact, "the old Russian tradition of religious personalism," as represented by philosophers such as Soloviev and Berdiaev, existed in combination with Kantian idealism. This combination was conspicuous in Russian neo-idealist liberal theory in the late nineteenth and early twentieth centuries, and it produced a robust and theoretically sophisticated defense of human dignity and human rights - decades before Maritain and the Universal Declaration of Human Rights. ${ }^{3}$ Moyn might be right in claiming that "Kantians were few and far between in the 1940s," but they were clearly present in pre-revolutionary Russian philosophical liberalism, where they were at home with Orthodox Christian personalists. The history of human rights in Russian neo-idealism thus calls into question the claims of the recent historiography that human rights, after their initial formulation in the Atlantic revolutions of the late eighteenth century, "almost disappeared from political and legal discourse in the nineteenth century" and that "human rights in their specific contemporary connotations are a relatively recent invention" $[17, \mathrm{pp} .1,3]$.

As I noted above, Helen Iswolsky regarded Vladimir Soloviev as "the precursor of the Christian humanism of our times." Maritain's "integral humanism” is indeed strikingly similar to Soloviev's Christian humanism. To see that, let us turn first to Soloviev, then (and in more detail) to Maritain. The central concept of Soloviev's whole religious philosophy is the concept of bogochelovechestvo, variously translated as Godmanhood, theanthropy, divine humanity, or the humanity of God. According to Paul Valliere, "the concept of bogochelovechestvo was the vehicle for a principled and profound Orthodox Christian humanism" [18, p. 12]. It refers to humanity's divine potential and vocation, the ideal of our divine self-realization in and union with God. The patristic doctrine of theosis, or salvation as deification, is the theological core of the concept of bogochelovechestvo, but Soloviev dramatically broadened it, shifting the emphasis from mysticism, monastic contemplation, and asceticism to an activist, socially-premised conception of human perfectibility [19]. Bogochelovechestvo is, in short, the divine-human project of building the Kingdom of God.

Soloviev based his concept of bogochelovechestvo on his philosophical anthropology, or conception of human nature. In this he closely followed Kant's teaching on human dignity ${ }^{4}$, which has been vastly influential ever since it appeared in the Groundwork of the Metaphysics of Morals in 1785. Kant's key argument is that the ground of human dignity consists in the dual capacity of reason (first) to recognize or posit ideals such as the moral

${ }^{3}$ The living link between pre-revolutionary Russian neo-idealism and the Universal Declaration of Human Rights was Sergius Hessen (1887-1950), on whom see [16, ch. 7]. Hessen contributed a chapter to the UNESCO volume on the philosophy of human rights, "The Rights of Man in Liberalism, Socialism and Communism". In Walicki's words, "It seems justified, therefore, to say that the man who embodied the last link in the progressive evolution of Russian liberalism, who was so deeply steeped in the traditions of Russian thought, fully participated in preparing the Charter of Human Rights for our times" [16, p. 439].

${ }^{4}$ As did, before him, Boris Chicherin [20, p. 285-290]. 
law and (second) to determine the will according to such ideals. Kant called this core human capacity the autonomy of the will or self-determination.

In his Lectures on bogochelovechestvo (delivered in 1878), his doctoral thesis Critique of Abstract Principles (defended and published in 1880), and in other works, Soloviev stipulates that human beings combine in themselves three principles: the absolute or divine principle, the material principle, and (between them) the distinctively human principle, which is rational autonomy or the capacity for self-determination ${ }^{5}$. He derived the middle, human principle of autonomy entirely from Kant ${ }^{6}$. Bogochelovechestvo combines the divine and human principles. It is the free human realization of the divine idea in ourselves and in the world: again, deification or theosis. Soloviev always maintained that bogochelovechestvo could not be achieved without human autonomy: "The divine content must be appropriated by a human being from within himself, consciously and freely," through the fullest development of human rationality [23, p. 410]. The autonomy and perfectibility by which our intrinsic potential divinity alone can be realized from the ground of human dignity. Salvation apart from self-determination would violate human dignity or at any rate be accomplished past it.

The Russian philosopher Semën Frank wrote that the concept of bogochelovechestvo extends the Chalcedonian dogma of Christ the God-man's two natures to all of the existence [24, pp. 15-16]. It extends it, at any rate, to all human persons. I would argue that the concept is a distinctively Kantian interpretation of Chalcedon that emphasizes the autonomy of the human principle relative to the divine. In every human person, the divine element (the "image of God" in us) must be freely recognized and embraced by the human element (that is, by reason and will). Our task is to bring our nature into ever closer "likeness" or conformity with God. Christ achieved this perfect conformity, and he did so through an act of the rational human will. As Oliver Smith put it, "The humanity of Christ is 'spiritualized' or divinized not despite his humanity but because of it" [25, p. 119]. We are to follow Jesus' example and teaching: "Be perfect even as your Father in heaven is perfect" (Matthew 5: 48, one of Soloviev's favorite verses). This is the true, divine-human path to the kingdom of God: divine in that God is the ideal of perfection, human in that the task of perfectibility is ours. Soloviev followed Kant in thinking that the kingdom of God could come only through the kingdom of ends, Kant's famous ideal of a moral order whose members respect each other as persons or ends-in-themselves ${ }^{7}$.

Soloviev's most powerful and systematic defense of human dignity is a Justification of the Good (1897), one of the great modern works of moral and religious philosophy. The very concept of the "justification of the good" is human perfectibility or progress toward bogochelovechestvo. In his treatise, Soloviev called Kant's conception of morality "one of the greatest achievements of the human mind" [27, p. 135]. He preferred to speak of the divine principle or divine image in us, but it functioned as the ideal just like Kant's moral law, while the human "likeness" to God described our capacity for self-determination and

${ }^{5}$ This and next three paragraphs are drawn from [20, pp. 291-293]. For further development see [21].

${ }^{6}$ In Critique of Abstract Principles, Soloviev closely paraphrases and directly translates large parts of the Groundwork of the Metaphysic of Morals [22, pp. 44-62]. In addition to these two chapters, he devotes three more, plus an appendix, to Kant's ethics and conception of rational autonomy, drawing also on (paraphrasing and quoting at length) the Critique of Pure Reason and the Critique of Practical Reason [22, pp. 62-72, 89-116, 371-397].

${ }^{7}$ For further development, see [26]. 
infinite perfectibility according to the image or ideal $[27, \text { p. } 145]^{8}$. This "double infinity" of the image and likeness belongs to everyone. "It is in this that the absolute significance, dignity, and worth of human personhood consist, and this is the basis of its inalienable rights"9. That is one of the most significant statements in Soloviev's whole corpus: it formulates modern Christian Orthodox personalism, does so in a Kantian framework, and makes the explicit connection to human rights. In another capacious passage, he wrote: "The absolute value of a man is based, as we know, upon the possibility inherent in his reason and his will of infinitely approaching perfection or, according to the patristic expression, the possibility of becoming divine (theosis)" [27, p. 296].

Soloviev consistently held that human perfectibility (again, progress toward bogochelovechestvo) is realized in society and develops in history. In his social philosophy, he embraced the idea of natural law, which he thought ought to guide the actual, historical development of positive law as its rational essence and normative ideal. The goal is an ever more lawful and just society, and the ever fuller realization of human potential. In his words, "Freedom, as the foundation of all human existence, and equality, as the necessary form of all societal existence, in combination form human society as a lawful order" $[22, \text { p. 155 }]^{10}$. Law is essential but not the highest principle of Soloviev's social philosophy. It deals with the means by which people pursue their ends, not the ends themselves (which ends Soloviev defined as the pursuit of moral perfection in the free unity of spiritual love). He directly followed Kant in defining his social ideal as the ethical (and not merely juridical) community of the "kingdom of ends," which both philosophers thought of as the church. Soloviev called it "free theocracy"11.

With that overview of Soloviev, we can proceed to Maritain. Their conceptions of Christian humanism are strikingly similar. This is obvious first of all in that Maritain's "integral humanism" integrates the human and divine, just as bogochelovechestvo does. Both philosophers agreed on the main principles of Christian humanism. Let me identify the five most important. First, the essential principle of integral humanism is the human capacity for self-determination toward and integration into the divine. Second, that capacity is the ground of human dignity, a paramount principle for both philosophers. Third, and closely related to the principle of human dignity, is their Christian personalism: the idea that human beings are persons because they are created in the image and likeness of God and are called to progressively realize the divine likeness in themselves, in society, and in the world. Fourth, the transcendent fulfillment of human self-determination

${ }^{8}$ This interpretation of Genesis 1: 26 was not original with Soloviev but can be traced to the Eastern Church Fathers. Patrick L. Michelson has reconstructed the history of the idea of "similitude anthropology" - free "assimilation to God" and "moral deification" — and its Russian reception [28].

${ }_{9}^{9}$ [27, p. 176]. At points I have modified the Duddington translation in accordance with the Russian text: Soloviev, V.S. (1911), "Opravdanie dobra: nravstvennaia filosofiia", in Sobranie sochinenii Vladimira Sergeevicha Solovieva, vol. 8, Prosveshchenie Publ., St. Petersburg, Russia, pp. 3-516.

${ }^{10}$ Despite certain changes in his legal philosophy in Justification of the Good, Soloviev remained convinced of the basic principles of law that he set forth in Critique of Abstract Principles. He reprinted its two main chapters on law, together with two sections from Justification of the Good, in Law and Morality: Essays in Applied Ethics (1897), which serves as a good overall statement of his philosophy of law [29]. For astute analyses of Soloviev's social and legal philosophy, see [16, pp. 165-212; 30].

${ }^{11}$ For details, see [26, pp. 223-228]. 
toward and integration into the divine is theosis or deification ${ }^{12}$. Fifth is a social philosophy of historical progress oriented toward the suprahistorical ideal of the kingdom of God. It is a social philosophy premised on human dignity, human rights, and the rule of law, though both philosophers saw it as leading toward a qualitative moral transformation in human relations, in which, presumably toward the end of history, law would give way to love - a love at once divine and fraternal. Soloviev called this social ideal "free theocracy", and Maritain called it the "historical ideal of a new Christendom". Both philosophers used the term "Christian politics" as the way toward the ideal.

In Integral Humanism, Maritain devotes much attention to Russia Communism and to the Soviet situation, with numerous references to Iswolsky, Berdiaev, Dostoevsky, Waldemar Gurian, Boris Souvarine, Marx, Lenin, Bukharin, and even Gorky. There is only one reference to Soloviev, and it is not particularly significant [4, p. 194]. Nonetheless, an explication of Maritain's text will demonstrate that the religious philosophies of both thinkers are "integral humanisms." Other scholars are also pursuing this comparison $[31]^{13}$. In 2008, there appeared an edited volume, Vladimir Soloviev, Jacques Maritain: Le personnalisme chrétien [32].

In his treatise Maritain characterizes integral humanism as "a theocentric or truly Christian humanism," in contrast to anthropocentric humanism, which has dominated the modern era, with roots in the Renaissance and Reformation, and which tends towards naturalism and atheism [4, p. 169]. The roots of integral humanism are in medieval Christendom, which "embodied in its sacral forms a virtual and implicit humanism." This implicit humanism began to manifest itself in the twelfth and thirteenth centuries, especially with St. Thomas Aquinas, but the modern era displaced it. Maritain's project is the revival of integral humanism, but in a modern form - "no longer sacral but secular or lay". In the face of contemporary inhuman ideologies such as fascism and communism, he hoped that integral humanism could meet the pressing Christian need for "a sound social philosophy and a sound philosophy of modern history". He saw it has the heart of a new Christendom [4, p. 155].

In the same way that some humanisms are irreligious or indeed antireligious, obviously not all conceptions of religion qualify as humanistic. Maritain refers to a "certain theological inhumanity" in medieval Catholicism that came from the "less sound parts of the Augustinian synthesis." He hastens to add that "St. Thomas put everything in order again, but too late for medieval thought to be able to profit from his principles and bring them to fruition" [4, pp. 159-160]. His harshest indictment is directed against his contemporary Karl Barth, whose position he describes as archaic and as marked by a return to the pure pessimism of primitive Protestantism (especially Calvinism), by primordial antihumanism, and by the annihilation of man before God [4, p. 196]. The way

${ }^{12}$ In Integral Humanism, Maritain does not use the term deification. He writes rather of the conquest of freedom, spiritual perfection, and attainment to the very life of God. However, in his seminal 1940 article "The Conquest of Freedom", he defines that conquest as deification.

${ }^{13}$ Ana Siljak (Queen's University, Ontario, Canada) has written papers exploring the connections between French Catholic and Russian Orthodox personalism in interwar France, within the context of the twentieth-century history of human rights. 
forward, toward a new Christendom animated by the ideal of the kingdom of God, is the "integralist and progressive" position of Catholicism, especially of St. Thomas Aquinas [4, p. 196]. Maritain wrote simply: "I think that the theology of St. Thomas will dominate a new Christendom" [4, p. 199]. The "new age of Christian culture" that he hoped for would be an age of integral humanism, in which "the creature would not be belittled or annihilated before God; and neither would it be rehabilitated without God or against God; it would be rehabilitated in God". Integral humanism is the "humanism of the Incarnation". To return to it "is to save the 'humanist' truths disfigured by four centuries of anthropocentric humanism" [4, p. 197].

What are these truths that are to be saved, restored, and (where necessary) modernized by integral humanism? I would enumerate them as follows. They largely overlap with the five shared principles that I listed above, but the following five are specific to Maritain (he does not precisely list them). First is personalism, which is the core of integral humanism. In a famous formulation, Maritain wrote:

A person is a universe of spiritual nature endowed with freedom of choice and constituting to this extent a whole which is independent in face of the world - neither nature nor the State can lay hold on this universe without its permission. And God himself, who is and acts within, acts there in a particular manner and with a particularly exquisite delicacy, which shows the value He sets on it: He respects its freedom, at the heart of which He nevertheless lives; He solicits it, He never forces it $[4$, p. 158].

The value that God places on the human person and his respect for its freedom are markers of human dignity, the second truth of integral humanism, closely related to the first ${ }^{14}$. Freedom is an essential human quality, but it must be properly integrated with grace. Their integration - "holy freedom", as Maritain once calls it [4, p. 255] — is the third truth of integral humanism. It is part of what Maritain calls the Christian conception of man, according to which man (or the human person) "is made for a supernatural end: to see God as God sees himself, he is made to attain to the very life of God; he is traversed by the solicitations of actual grace, and if he does not oppose his power of refusal, he bears within him even here below the properly divine life of sanctifying grace and its gifts" [4, p. 158]. The supernatural end of attaining to the very life of God is deification or theosis, the fourth truth of integral humanism [5, pp. 173-179].

This supernatural end enjoins human beings to work for the kingdom of God, an ultimately transcendent ideal but one that ought to be approximated by the "socio-temporal realization of the Gospel truths" [4, pp. 155, 179, 211], or by what Maritain, like Soloviev, calls "Christian politics" [4, pp. 227, 293]. Human work toward the kingdom of God is the fifth truth of integral humanism. In a particularly rich passage, Maritain explains how "temporal history prepares enigmatically its final consummation in the kingdom of God":

[T] he aim that the Christian sets himself in his temporal activity is not to make of this world itself the kingdom of God, it is to make of this world, according to the historical ideal required by the different ages... the place of a truly and fully human earthly life, i.e., one which is assuredly full of defects, but it is also full of love, whose social structures have as their measure justice, the

${ }^{14}$ In Maritain's words, integral humanism "really and effectively respects human dignity and does justice to the integral demands of the person" [4, p. 155]. 
dignity of the human person, and fraternal love, and which to this extent prepares the coming of the kingdom of God in a filial, not servile, manner [4, pp. 221-222].

Today's historical ideal is that of a new Christendom, founded on the same principles, analogically applied, as medieval Christendom, but essentially distinct because it would be modern. For this Christian civilization, Maritain wrote in words that could have been Soloviev's, "to progress toward God will be, it seems above all, to prepare for man the terrestrial conditions of a life into which sovereign love can descend and make in man and with him a work divinely human" [4, p. 199].

Maritain devotes two chapters (the fourth and fifth) of Integral Humanism to the "historical ideal of a new Christendom". He lays the groundwork in the preceding chapter ("The Christian and the World") by emphasizing the importance for Christian social philosophy of the distinction between the temporal and spiritual orders, according to which the latter must vivify the former [4, pp. 214, 223]. The problem of the kingdom of God is crucial to understanding the proper relationship between the two orders. In an early and prescient analysis, Maritain distinguishes between the German concept politische Theologie and the French concept théologie politique. "The French meaning... is that politics, like everything that relates to the moral order, is a subject for the theologian as well as for the philosopher, because of the primacy of the moral and spiritual values engaged in the political order itself" [4, p. 215]. In other words, théologie politique is the theological critique of politics by higher moral and spiritual values such as justice and human dignity. Such a critique is possible because the spiritual/temporal distinction is preserved.

By contrast, politische Theologie, at least in Carl Schmitt's version (to which Maritain refers), represents the political as "theological," meaning that, as Maritain puts it, "political realities are themselves of the divine or sacred order" [4, p. 215]. If political realities are absolute, "total", or "holy" ones, as Schmitt contends, then there are no higher values according to which they might be critiqued or by which their power might be limited. In short, Schmitt's conception of political theology obliterates the distinction between the temporal and the spiritual, and in the process absolutizes the political. A similar obliteration and resultant absolutization can be observed in the closely related idea of totalitarian ideologies as "political religions". According to that idea (advanced contemporaneously by Berdiaev, René Fülöp-Miller, Waldemar Gurian, Eric Voegelin, and others), communism and fascism were secularized forms of millenarianism and eschatology. Maritain devotes many pages to various aspects of this idea, analyzing the "religious atheism of Soviet Communism" [4, p. 190] and observing that "Marxism expects salvation and the realization, as it were, of the kingdom of God" [4, p. 184 and ch. 2 passim].

The "historical ideal of a new Christendom" restores the temporal/spiritual distinction effaced by totalitarianism. It refers to a secular, modern temporal order, but one oriented toward the spiritual order of the kingdom of God. It is, in short, the heart of integral humanism as a Christian social or political philosophy. A new Christendom would have some features in common with medieval Christendom and some distinctive features.

Maritain identifies three common aspects of Christendom as a temporal city "abstractly considered" (that is, whether medieval or modern): communal, personalist, and "peregrinal". By communal he means that the city (or society) has a common good that is higher than the individual goods and interests of its members, insofar as the latter are parts of the social whole. "This common good is essentially the right earthly life of the 
assembled multitude, of a whole composed of human persons". However, "this temporal common good is not the ultimate end. It is ordered to something better: the intemporal good of the person, the conquest of his perfection and spiritual freedom" [4, pp. 236$237]^{15}$. Hence the personalist aspect: it is essential that the temporal common good "respect and serve the supratemporal ends of the human person". The temporal common good has its own goodness, "but precisely on condition that it recognize this subordination and that it not make of itself the absolute good". In sum: the highest end of political society is "that each person will be positively aided in the progressive conquest of his full life as a person and of his spiritual freedom" [4, p. 237]. Maritain believes that there is something of an antinomy between the communal and personalist aspects: persons (as individual members of society) are subordinate parts of a greater temporal common good, yet (in their supratemporal destiny) they are also the ends to which it is subordinate [4, p. 238]. Finally, the "peregrinal" aspect of the temporal city refers to its being but a moment, the earthly moment, in the spiritual destiny of persons. In it, persons are en route and will leave it behind [4, p. 239].

In addition to the three features that it shares with the medieval sacral conception, the historical ideal of a new Christendom (modern and secular) has several features of its own. It is pluralist ("organic heterogeneity in the very structure of civil society"); it insists on the autonomy of the temporal order; it is resolutely committed to the freedom of persons, to their fundamental equality, and to democracy; and its main principle and task is the realization of a fraternal community and the cultivation of a love at once divine and human. Maritain's exposition of some of these features is involved, especially their distinctiveness relative to the medieval sacral order. These principles of a new Christendom are carried into his next works on political philosophy, where they are presented more clearly. But it worth quoting one of his concluding statements, which also could have been Soloviev's: Under a new Christendom, "there would begin to flower the integral humanism, the humanism of the Incarnation... which would admit of no other theocracy than that of divine love" [4, p. 306].

By 1940, Maritain was turning integral humanism into an explicit defense of human rights. His 1942 book The Rights of Man and Natural Law clearly shows this development. Both of these ideas - human rights and natural law - are new compared to Integral Humanism. Human dignity was all along one of Maritain's main principles, but from it he now gets to human rights through the idea of natural law. But first, he identifies four principles of a genuinely free society or democracy ${ }^{16}$, all directly from his 1936 treatise: personalism, communalism, pluralism, and theism. Personalism remains paramount. Maritain writes that "an essential characteristic of any civilization worthy of the name is respect and feeling for the dignity of the human person" [6, p. 65-66]. He emphasizes that

${ }^{15}$ Again, in "The Conquest of Freedom", Maritain defines this as deification.

16 "Democracy" is his preferred term because he thinks it most readily conveys the idea of human dignity. He strongly dislikes the term "liberalism", which he associates with the discredited French Third Republic that capitulated before the Nazis. He also uses the more elaborate term "humanist political philosophy", but call it what you will his political philosophy is a form of liberalism - one that has striking similarities with Russian philosophical liberalism. After all, fundamentally liberalism is a political philosophy grounded in human rights and their defense. 
human personhood is an irreducible mystery that invokes comparison with the divine. In a significant passage, he writes: "The worth of the person, his liberty, his rights arise from the order of naturally sacred things which bear upon them the imprint of the Father of Being and which have in him the goal of their movement. A person possesses absolute dignity because he is in direct relationship with the Absolute, in which alone he can find his complete fulfillment" [6, p. 67]. In short, "the person is a spiritual whole made for the Absolute" [6, p. 112].

Clearly, Maritain's understanding of human dignity and of personhood is explicitly metaphysical and theistic, so that the first and fourth principles - personalism and theism - of his integral humanist political philosophy are inherent in each other. Maritain is aware that "strangers to Christian philosophy" and even non-theists can have a "profound and authentic" appreciation for human dignity, but his view is that Christian philosophy, especially his own Thomism, is the highest rational justification of it [6, p. 67].

His second and third principles are communalism and pluralism. "The person is whole," Maritain writes, "but he is not a closed whole, he is an open whole" [6, p. 68]. Human beings are by their nature communal and social. The first chapter of The Rights of Man and Natural Law is called "A Society of Human Persons." It, too, draws directly on Integral Humanism. Society is oriented toward the common good, but this is the common good of human persons, so no one of them can be treated merely as a means for the end of the common good. Persons are the ends of the common good; society exists for their fullest possible self-realization and highest fulfillment. "The common good of society is their communion in the good life" [6, p. 70]. Ultimately that communion is in the Absolute or in the Kingdom of God, so "the human person transcends all temporal societies and is superior to them" [6, p. 73].

The third principle, pluralism, flows naturally from the quality of persons being free wholes. On this personalist foundation Maritain uses the principle of pluralism primarily to stand for a free society that consists of "autonomous communities which have their own rights, liberties and authorities" (e. g., the family, civil society, state, church, and international community). Though Maritain did favor progress toward what he called a "vitally Christian society," he opposed every form of religious coercion or clericalism and insisted that the principle of pluralism meant respect for freedom of conscience at all levels of society.

We can now return to the problem of what Maritain sees as the true sources of faith in human dignity and in human rights. Maritain was one of the great philosophers of human dignity. He held human dignity to be the source or ground of human rights, but that begs the question, What is the source or sources of human dignity or of absolute human value? One easy answer for the theist is "God", but that is a source in some sense external to human nature and so such an answer is, on its own, inadequate for the humanist. Maritain the humanist identifies three sources within human nature: reason, freedom, and love, capacities which give the person a "spiritual superexistence" or soul. But Maritain the theist knows that the ultimate source of human dignity, as of everything, is God. His solution is the concept of natural law, which enables him to integrate both approaches. He defines natural law as "an order or a disposition which human reason can discover and according to which the human will must act in order to attune itself to the necessary ends of the human being" [6, p. 104]. Maritain believed that natural law came from God and that, moreover, it provided rational grounds for theistic belief. But human nature, he writes, "is in itself suf- 
ficient to convince us that... natural law is something as real in the moral realm as the laws of growth and senescence in the physical" [6, p. 104]. Natural law - in our knowledge of it and in our capacity for self-determination according to it - was the source of human dignity and of the rights that come from such dignity. For theists like Maritain, it also provided grounds for belief in a transcendent divine reality. Natural law was the specific way his integral humanism was, or rather became, a philosophy of human rights.

Maritain's integral humanism did not become an explicit philosophy of human rights until about 1940. By contrast, "the old Russian tradition of religious personalism" was a philosophy of human rights from its origins in the pre-revolutionary period. Soloviev's legacy inspired the seminal work Problems of Idealism, which appeared in 1902 and which advanced a neo-idealist conception of personhood and of human rights [33]. The volume's impressive exposition of the philosophical foundations of liberalism strategically coincided - as its organizers intended - with the first stages of the Russian Liberation Movement that would culminate in the Revolution of 1905 . The project was planned by Peter Struve, who had just completed his evolution from Marxism to idealism, and by Pavel Novgorodtsev, a legal philosopher at Moscow University. Like Maritain later, they grounded human rights in natural law.

In 1901, as he was planning Problems of Idealism, Struve published one of his most remarkable essays (and dedicated it to Soloviev), "What is True Nationalism?" [34] ${ }^{17}$. For him, any true nationalism must rest on true liberalism, or on recognition of the absolute value of the person. He extols the Kantian principle of human dignity through individual self-determination, stating that it ought to be the moral foundation of any just social or political order [34, pp. 503, 504, 511, 520]. The fullest realization of personhood requires, in turn, the guarantee of individual rights: "The idea and practice of such rights, in our view, reveal all the deep philosophical meaning and all the enormous practical significance of the remarkable doctrine of natural law, lying at the basis of all true liberalism." Natural law is absolute, "rooted in the ethical concept of the person and its self-realization, and serving as the measure of all positive law" [34, p. 507]. True liberalism demands "recognition of the inalienable rights of the person," which rights cannot be trumped by any higher national or state values. Thus it is "also the only form of true nationalism" [34, p. 512 $]^{18}$.

Struve's own contribution to Problems of Idealism did not directly address the topic of natural or human rights, but several other contributions did. Novgorodtsev devoted his (masterful) chapter to the revival of natural law. He contrasts the medieval conception of natural law (which tended to identify it with the will of God) to its modern meaning, which is the inalienable rights of the person. Echoing Struve, he wrote, "Natural law is the expression of the autonomous, absolute significance of the person, a significance that must belong to it in any political system. In this respect natural law is more than a demand for

17 The article was published under the pseudonym "P. Borisov." Reprinted in Struve, P. (1902), Na raznye temy (1893-1901 gg.): Sbornik statei, Tipografiia A. E. Kolininskogo, St. Petersburg, Russia, pp. 526555. For analysis see [35, pp. 300-307].

18 Struve later reversed himself on this position. In his famous 1908 essay, "Great Russia," he advanced a Darwinian conception of the state as a "special organism" that lived by its own supreme laws of existence (such as the striving for power) and that was not subject to any higher law. See [36]. For analysis see [37, pp. 88-92]. 
better legislation: it represents the protest of the person against state absolutism, reminding us of the unconditional moral basis that is the only proper foundation of society and the state" [33, p. 313]. Berdiaev also contributed to Problems of Idealism. In one passage he writes: "Legal and political progress is nothing other than the realization and guaranteeing of the absolute natural rights of man, which need no historical sanction because these rights are the immediate expression of the moral law, given before any experience" [33, p. 178].

In conclusion, I would suggest that its neo-idealist, Christian personalist defense of human rights distinguished Russian liberalism from other contemporary European liberalisms, such as British utilitarianism, which were generally positivistic in their philosophical foundations. If there were a relative paucity of appeals to human rights in nineteenth-century European liberalism as a whole, as some historians today claim, then this philosophical difference might help to explain it. That difference might also explain why Maritain, Catholic and Thomist, found so much in common with his Orthodox and Kantian Russian predecessors.

\section{References}

1. Moyn, S. (2010), The Last Utopia: Human Rights in History, Harvard University Press, Cambridge, MA, USA.

2. Moyn, S. (2015), Christian Human Rights, University of Pennsylvania Press, Philadelphia, PA, USA.

3. Moyn, S. (2011), "Personalism, Community, and the Origin of Human Rights," in Hoffman, S.-L., ed., Human Rights in the Twentieth Century, Cambridge University Press, Cambridge, UK, pp. 85-106.

4. Maritain, J. (1996), Integral Humanism, in Maritain, J., Integral Humanism, Freedom in the Modern World, and a Letter on Independence, ed. by Bird, O., transl. by Bird, O., Evans, J. and O'Sullivan, R., University of Notre Dame Press, Notre Dame, IN, USA, pp. 143-345.

5. Maritain, J. (1962), “The Conquest of Freedom," in Gallagher, D. and Gallagher, I., eds, The Education of Man: The Educational Philosophy of Jacques Maritain, Doubleday, Garden City, NY, USA, pp. 159-179.

6. Maritain, J. (2011), The Rights of Man and Natural Law, in Maritain, J., Christianity and Democracy, The Rights of Man and Natural Law, transl. by Anson, D. C., intro. Gallagher, D. A., Ignatius Press, San Francisco, CA, USA, pp. 63-138.

7. Maritain, J. (1951), Man and the State, University of Chicago Press, Chicago, IL, USA.

8. Rosen, M. (2012), Dignity: Its History and Meaning, Harvard University Press, Cambridge, MA, USA.

9. UNESCO (1949), Human Rights: Comments and Interpretations, intro. Maritain, J., Columbia University Press, New York, NY, USA.

10. Lauren, p. G. (2011), The Evolution of International Human Rights: Visions Seen, $3^{\text {rd }}$ ed., University of Pennsylvania Press, Philadelphia, PA, USA.

11. McInerny, R. (2003), The Very Rich Hours of Jacques Maritain: A Spiritual Life, University of Notre Dame Press, Notre Dame, IN, USA.

12. Maritain, J. (2007), "Jacques Maritain: The Grounds for an International Declaration of Human Rights" (1947), in Ishay, M., ed., The Human Rights Reader, $2^{\text {nd }}$ ed., Routledge, New York, NY, USA, pp. 2-6.

13. Emerson, C. (2014), "Jacques Maritain and the Catholic Muse in Louriés Post-Petersburg Worlds," in Móricz, K. and Morrison, S., eds, Funeral Games in Honor of Arthur Vincent Lourié, Oxford University Press, Oxford, UK, pp. 196-268.

14. Iswolsky, H. (1942), Light Before Dusk: A Russian Catholic in France, 1923-1941, Longmans, Green and Co., New York, NY, USA.

15. Iswolsky, H. (1985), No Time to Grieve: An Autobiographical Journey, The Winchell Company, Philadelphia, PA, USA.

16. Walicki, A. (1987), Legal Philosophies of Russian Liberalism, Oxford University Press, Oxford, UK.

17. Hoffman, S.-L. (2011), "Introduction: Genealogies of Human Rights," in Hoffman, S.-L. (ed.), Human Rights in the Twentieth Century, Cambridge University Press, Cambridge, UK, pp. 1-26.

18. Valliere, p. (2000), Modern Russian Theology. Bukharev, Soloviev, Bulgakov. Orthodox Theology in a New Key, William B. Eerdmans Publishing Company, Grand Rapids, MI, USA. 
19. Gustafson, R. F. (1996), "Soloviev's Doctrine of Salvation," in Kornblatt, J. K. and Gustafson, R. F., eds, Russian Religious Thought, University of Wisconsin Press, Madison, WI, pp. 31-48.

20. Poole, R. (2017), "The Defense of Human Dignity in Nineteenth-Century Russian Thought," in Goldfrank, D., Nollan, V., and Spock, J. (eds), Iosif Volotskii and Eastern Christianity: Essays Across Seventeen Centuries, New Academia Publishing, Washington, D.C., USA, pp. 271-305.

21. Poole, R. (2010), "Vladimir Soloviev's Philosophical Anthropology: Autonomy, Dignity, and Perfectibility," in Hamburg, G. M. and Poole, R. A., eds, A History of Russian Philosophy, 1830-1930: Faith, Reason, and the Defense of Human Dignity, Cambridge University Press, Cambridge, UK, pp. 131-149.

22. Soloviev, V. (1911a), "Kritika otvlechennykh nachal" [Critique of Abstract Principles], in Soloviev, S. M. and Radlov, E. L., eds, Sobranie sochinenii Vladimira Sergeevicha Solovieva [Collected Works of Vladimir Sergeevich Soloviev], $2^{\text {nd }}$ ed., 10 vols., vol. 2, Prosveshchenie Publ., St. Petersburg, Russia, pp. iii-397.

23. Soloviev, V. (1911b), "Istoricheskie dela filosofii" [The historical deeds of philosophy], in Soloviev, S. M. and Radlov, E. L., eds, Sobranie sochinenii Vladimira Sergeevicha Solovieva [Collected Works of Vladimir Sergeevich Soloviev], $2^{\text {nd }}$ ed., 10 vols., vol. 2, Prosveshchenie Publ., St. Petersburg, Russia, pp. 401-413.

24. Frank, S. L. (1950), "Introduction," in Frank, S. L., ed., A Solovyov Anthology, transl. by Duddington, N., SCM Press, London, UK, pp. 9-31.

25. Smith, O. (2011), Vladimir Soloviev and the Spiritualization of Matter, Academic Studies Press, Boston, MA, USA.

26. Poole, R. (2014), "Kant and the Kingdom of Ends in Russian Religious Thought (Vladimir Solov'ev)," in Michelson, P. L. and Kornblatt, J. D., eds, Thinking Orthodox in Modern Russia: Culture, History, Context, University of wisconsin Press, Madison, WI, USA, pp. 215-234.

27. Solovyov, V. (2005), The Justification of the Good: An Essay on Moral Philosophy, transl. by Duddington, N. A., ed. and annotated Jakim, B., William B. Eerdmans Publishing Company, Grand Rapids, MI.

28. Michelson, P. L. (2007), "In the Image and Likeness of God: The Patristic Tradition of Human Dignity and Freedom in Nineteenth-Century Russia," in Michelson, P. L."The First and Most Sacred Right": Religious Freedom and the Liberation of the Russian Nation, 1825-1905. PhD dissertation, University of Wisconsin, Madison, pp. 29-92.

29. Soloviev, V. (2000), "Law and Morality: Essays in Applied Ethics", in Wozniuk, V., ed. and transl., Politics, Law, and Morality. Essays by V. S. Soloviev, Yale University Press, New Haven, CT, USA, pp. 131-212.

30. Valliere, P. (2006), "Vladimir Soloviev (1853-1900)", in Witte, J. and Alexander, F., eds, The Teachings of Modern Christianity on Law, Politics, and Human Nature, in 2 vols., vol. 1, Columbia University Press, New York, NY, USA, pp. 533-575.

31. Pribytkova, E. (2012), "Natural Law and Natural Rights according to Vladimir Solovyov and Jacques Maritain", in Brüning, A. and van der Zweerde, E. (eds), Orthodox Christianity and Human Rights, Peeters, Leuven, Belgium, pp. 69-82.

32. Laubier, D. P. de, ed. (2008), Vladimir Soloviev, Jacques Maritain: Le personnalisme chrétien, Les Presses universitaires de l'IPC, Paris, France.

33. Poole, R., ed. and transl. (2003), Problems of Idealism: Essays in Russian Social Philosophy, Yale University Press, New Haven, CT, USA.

34. Struve, P. B. (1901), "V chem zhe istinnyi natsionalizm?" Voprosy filosofii i psikhologii, vol. 12, no. 4, book 59, pp. 493-528. USA.

35. Pipes, R. (1970), Struve: Liberal on the Left, 1870-1905, Harvard University Press, Cambridge, MA,

36. Struve, P. B. (1908), "Velikaia Rossiia: Iz razmyshlenii o probleme russkogo mogushchestva" [Great Russia. Some reflections about the problem of Russian power], Russkaia mysl', vol. 29 (January), pp. 143157. USA.

37. Pipes, R. (1980), Struve: Liberal on the Right, 1905-1944, Harvard University Press, Cambridge, MA,

Author's information:

Randall A. Poole — PhD in History, Professor; rpoole@css.edu 
Концепции интегрального гуманизма: Жак Маритен, Владимир Соловьев и история прав человека

\author{
Рэндалл А. Пул \\ Колледж Св. Схоластики, \\ США, 55811, Миннесота, Дулут, Кенвуд Авеню, 1200
}

Для цитирования: Пул Рэндалл А. Концепции интегрального гуманизма: Жак Маритен, Владимир Соловьев и история прав человека // Вестник Санкт-Петербургского университета. Философия и конфликтология. 2019. Т. 35. Вып. 1. С. 92-106. https://doi.org/10.21638/spbu17.2019.108 (In English)

Сегодня как история, так и философское обоснование прав человека - вопросы оживленных научных дискуссий. Одной из видных фигур в подобных дебатах является Самуэль Мойн, профессор права и истории Гарвардского университета. Он утверждает, что всеобщие права человека - относительно недавняя концепция, они возникли в 1940-х годах и представляют собой продукт, в частности, католической философии той эпохи. «Изобрел» права человека католический мыслитель Жак Маритен. Он был одним из основателей французского философского движения, известного как персонализм, который он создал в своем собственном христианском (или «целостном») гуманизме. К 1940 г. он превратил интегральный гуманизм в явную и надежную защиту прав человека. В 1948 г. появилась Всеобщая декларация прав человека, а Маритен был одним из ее интеллектуальных архитекторов. Однако за десятилетия до Маритена другая традиция христианского персонализма уже превратилась в теорию прав человека. Это был российский неоидеализм. В конце XIX и начале XX вв. он сочетал православный христианский персонализм с кантианской концепцией человеческого достоинства, чтобы создать теоретически изощренную защиту прав человека. Ведущей фигурой в этом развитии был величайший религиозный философ России Владимир Соловьев. После русской революции интеллектуальное наследие Соловьева и русского неоидеализма было передано Николаем Бердяевым и русской философской эмиграцией в межвоенную Францию, где оно помогло сформировать среду, в которой сложилась мысль Маритена. Действительно, «интегральный гуманизм» Маритена поразительно похож на христианский гуманизм Соловьева.

Ключевые слова: человеческое достоинство, права человека, либерализм, персонализм, христианский гуманизм, русский неоидеализм, обожествление, богочеловечество, Кант, Жак Маритен, Владимир Соловьев, Николай Бердяев.

Статья поступила в редакцию 000002018 г.; рекомендована в печать 3 октября 2018 г.

Контактная информация:

Рэндалл А. Пул - канд. ист. наук, проф.; rpoole@css.edu 